\title{
Devotion to Jesus and Historical Investigation. A Grateful, Clarifying and Critical Response to Professor Casey
}

\author{
Larry W. Hurtado \\ New College, University of Edinburgh, Edinburgh, EH1 2LX \\ L.Hurtado@ed.ac.uk
}

It is obviously very gratifying to have my recent book (Lord Jesus Christ: Devotion to Jesus in Earliest Christianity, hereafter referred to as LJC) given the attention represented in Professor Casey's commissioned reviewessay. It is all the more encouraging to receive such a gracious and positive estimate of it, along with a constructive engagement with some central matters, by a scholar of Professor Casey's stature and competence. ${ }^{1}$ Given the limitations of space, and in respect for Professor Casey, in what follows I shall give particular attention to the matters highlighted in his discussion.

\section{Smaller Matters}

Before I turn to the matters deemed by Professor Casey as more important issues of disagreement, I would like to address briefly a few other items.

First, although Casey's summary of the contents and main emphases of $L J C$ is largely accurate, I must make at least one rather important correction. In the early chapter where I lay out my proposed model of the 'forces and factors' that I contend drove and shaped devotion to Jesus in the early period, I specify four (not three). In addition to those mentioned by Casey (Jewish monotheism with the role of 'principal agent' traditions, Jesus' ministry, and religious experiences), I also underscore the effects of the wider 'religious environment' of the Roman period. Then, in subsequent chapters where I conduct the historical analysis of devotion to Jesus, I try to illustrate the effects of all four of the 'forces and factors' that I propose.

1. I am also grateful to Dr Horrell (Editor of $J S N T$ ) for this opportunity to respond. 
Secondly, there are some subjects that I consider more important and substantial than is reflected in Casey's summary. He focuses on New Testament texts and issues (granted, quite properly for this journal), and only mentions very briefly that I also treat a good deal of other material and issues as well. Prominently among these, I devote four chapters (over 220 pages, about one-third of the book) to texts and developments mainly in the second century, because I think that these matters deserve such attention. Indeed, for historical analysis of earliest devotion to Jesus, I contend that it is highly instructive to set the New Testament texts and phenomena in this somewhat wider historical horizon. Moreover, the second-century texts, developments and expressions of devotion to Jesus are simply intriguing in their own right.

I turn now to a couple of small matters mentioned by Casey. First, although he deems it a relatively minor fault, he predicts scholarly dismay at my choice to cite the New Testament in English translation rather than in Greek, and he complains that I give only Greek words/phrases deemed crucial in transliteration. Well, had I written this book solely for fellow scholars, I suppose that I could have chosen to cite texts entirely in original languages. To be sure, I do intend $L J C$ as a major contribution to scholarly opinion in the subject. But I also wanted to make it reasonably accessible to a wider readership as well, including intelligent people interested in the subject but who may not necessarily have a reading ability in the several ancient languages of the evidence cited. It seems to me that the only justifiable cause for scholarly dismay would be if my translations or characterizations of texts (which, by the way, comprise considerably more than the New Testament, and in several languages including Greek, Latin, Hebrew, Aramaic and Coptic) were in any serious way inaccurate or misleading. Casey identifies no problem here, so it appears that he objects merely to my authorial choice of a slightly more diverse readership than he would intend to address.

There is, however, one hint that Professor Casey gives of a substantial dissatisfaction with my handling of the linguistic evidence. He alerts readers that I am 'not fully at home' in Aramaic, judging this evidence in my handling of 'the son of man' issues; but he graciously characterizes this as a minor defect, all too common among New Testament scholars. Inasmuch as I myself rather explicitly declare my limited competence in Aramaic (p. 303 n. 113), I do not dispute his basic observation.

But the unfortunate inference might be taken that my hesitation to assent to his views on the Aramaic background of the expression 'the son of 
man' is simply attributable to my less extensive expertise in the language. However, other unquestionably competent Aramaists also question Casey's claims, and their handling of the (very limited) Aramaic evidence available seems to me more rigorous and, therefore, more plausible. ${ }^{2}$

But let us turn now to the issues that Professor Casey highlights as more serious matters of disagreement.

\section{Exaggeration?}

Casey repeatedly claims that I exaggerate things in my characterization of earliest devotion to Jesus. He complains that my use of such terms as 'remarkable' and 'astonishing' are not appropriate to historical analysis. We shall simply have to disagree on this. In my view, if something is shown to be a major phenomenon, and is also novel, without real precedent or analogy, and therefore very difficult to account for by simple historical explanation, it is surely legitimate, perhaps even required, to characterize the phenomenon in such terms.

The crucial question, therefore, is whether earliest devotion to Jesus represents a major phenomenon that is also genuinely novel in the religious matrix within which it first appeared. Casey grants this somewhat, but then qualifies it, noting that in a chapter of his 1991 book he illustrated how ancient Jewish tradition was able to treat various figures in very exalted terms, and I agree. Actually, a few years earlier than Casey's Cadbury lectures appeared I devoted the bulk of a small book to making a basically similar point more extensively. ${ }^{3}$ But, as I have repeatedly emphasized, this honorific treatment of Old Testament heroes, principal angels, messianic figures or even divine attributes (such as Wisdom), although relevant and notable, never seems to have included anything like the pattern of devotional practices, including cultic devotion directed toward the figure of Jesus that appeared both early and quickly, and that, therefore, so obviously amounts to a notable new 'mutation' in Jewish religious tradition and

2. In addition to the studies cited in $L J C$, I now point to the recently completed $\mathrm{PhD}$ thesis by Albert Lukaszewski, 'The Value of Qumran Aramaic for Addressing the New Testament Aramaic Problem' (St Andrews University, 2004), which includes a full grammar of Qumran Aramaic.

3. Larry W. Hurtado, One God, One Lord: Early Christian Devotion and Ancient Jewish Monotheism (Philadelphia: Fortress Press; London: SCM Press, 1988; Edinburgh: T\&T Clark, 2nd edn, 1998; reprinted London: T\&T Clark International, 2003), esp. pp. 17-92. 
cultic practice of the time. ${ }^{4}$ I am puzzled that it appears to be necessary to make this point repeatedly, and that it seems so easy for many scholars to continue to underestimate the crucial significance of this unprecedented development.

As I have said, however, Casey actually grants this basic point, admitting that the evidence that I marshal points to something 'real and important', amounting to 'a modification of Jewish monotheism'. But he demurs from my judgment that this amounts to an early 'binitarian' pattern of worship, at least prior to the probable date of the Gospel of John, accusing me of using 'evangelical rather than analytical categories' and, in particular, of giving 'an exaggerated description of the position of Jesus in Paul'. ${ }^{5} \mathrm{He}$ also claims that in LJC I have now re-defined 'binitarian' in comparison with my previous usage of it, so that what I now mean by the term is not really so objectionable as formerly. These accusations require a rather direct response.

Let us consider the latter accusation first. It is no academic sin for a scholar to adjust a position in light of further reflection and debate, and I hope that I am able to do so. But Casey is simply incorrect to claim that my use of 'binitarian' in $L J C$ represents any real departure from my previous and quite specific definition of the term. From my 1988 book onward, I have emphasized a pattern of cultic devotional practice in early Christian circles in which Jesus was accorded a role and status that linked him with God in an unprecedented way; yet also, characteristically, cultic reverence of Jesus was practiced as part of the worship of, and in obedience to, the one God, and not as the worship (or apotheosis) of a second deity. ${ }^{6}$ That is, two figures (God and Jesus) are linked uniquely in their devotional life, but, for them, reverencing Jesus is an essential expression of reverence for the one God ('the Father', e.g., Phil. 2.9-11). I cannot see anything specifically different in my characterization of early Christian 'binitarian' worship in $L J C$ than I have underscored from 1988 onward.

Moreover, I simply do not see that Casey's charge that I exaggerate the

4. As I have specified extensively in several publications (including $L J C$, pp. 13453) the phenomena that comprise this innovative pattern of devotion, I shall not reiterate this discussion here.

5. I confess that I cannot intuit what Casey means by 'evangelical' as a descriptor of some of my words. Does he use the term colloquially to connote exaggeration and over-enthusiastic description, or something else? So, I deal here with what I take to be the substance of the matter between us.

6. E.g., One God, One Lord, pp. 98-100, 121. 
import of the evidence in Paul and other texts such as Revelation is justified. As I have said already, he grants that the phenomena that I point to comprise 'new and unique features' in the context of second-temple Jewish religion. It seems to me that at the bottom of Casey's reluctance to face what I regard as the full import of the evidence is a rigid syllogism that involves some dubious components. (1) If the reverence of Jesus by Jewish Christians (among whom Casey rightly includes Paul) effectively amounted to 'binitarian' worship, then Jewish monotheism would have been 'breached'. (2) It is inconceivable that Jewish Christians would have breached Jewish monotheism. (3) Therefore, it is an exaggeration to characterize their devotional pattern as 'binitarian'. If only we could settle historical matters so simply! ${ }^{7}$ The limited space here requires that I must refer readers to my discussion of the evidence (esp. pp. 79-216), and to my argument that the history of religions shows how significant reconfiguring of beliefs and practice can happen within a religious tradition (LJC, pp. 64-74).

\section{Johannine Christianity}

Casey's remaining major objection has to do with my construal of Johannine evidence in particular. With many other scholars, I see the Gospel of John as reflecting an expulsion of Jewish Christians from their larger Jewish community on account of their devotion to Jesus, which happened at a point sufficiently close to the composition of John that the bitterness of that experience surfaces repeatedly in the text. ${ }^{8}$ Casey complains that I

7. In fact, on several matters Casey seems to me to operate in a dubiously deductive manner, as in the line of reasoning in his self-quotation toward the end of his essay. Starting from the premise, a fiat that Jesus' divine status is 'inherently unJewish', he deduces that Jesus was made divine in Johannine Christianity only when it 'took on Gentile self-identification', which, he then reasons, must mean ('It follows') that 'the development of New Testament christology' cannot have been guided by the Holy Spirit. With great respect for Professor Casey's erudition, I am bound to say that this statement involves insufficiently considered assumptions and puzzling leaps in logic that space does not permit me to engage further here.

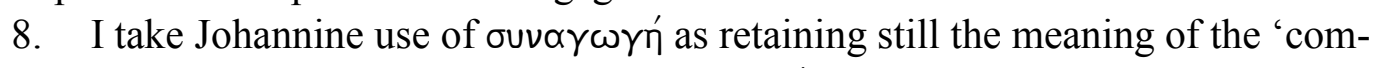

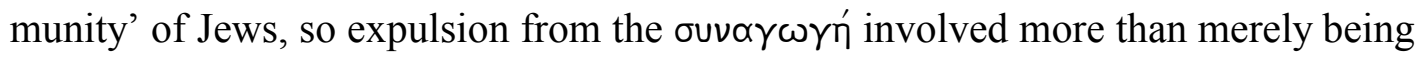
denied attendance at meeting-places of Jews for prayer. Also, unlike Casey, I do not take Johannine references to 'the Jews' as indicative of 'Gentile self-identification'. Paul, who continued to identify himself as a Jew after his own embrace of faith in 
overemphasize the importance of Jewish Christians in Johannine Christianity, and he accuses me of failing to do justice to "the social identity of Christian communities'. But what he really appears to mean is that I do not consent to his theory that particularly in Johannine Christianity 'Gentile self-identification' caused Jesus to become 'fully divine' and 'fully God', as 'the restraining factor of Jewish monotheism was removed [italics his]'. In $L J C$, I briefly give reasons for being unpersuaded, and I must declare that I remain unrepentant. ${ }^{9}$

One key reason will suffice here. I take the accusations against Jesus in 10.31-39 and 19.7 as actually reflecting the sort of charges levelled against Johannine Jewish Christians, and that finally led to their expulsion from their Jewish community. That is, accusations of blasphemy by Jewish authorities did not commence with a supposed dominance of 'Gentile selfidentification', but arose in response to the reverence for Jesus by Johannine Jewish Christians, and that led to their expulsion in the post- $70 \mathrm{CE}$ efforts led by Yavnean authorities to consolidate Judaism. ${ }^{10}$

Of course, I do not dispute the influx of Gentile converts, into Johannine circles, Pauline churches and others as well. But it is anachronistic to attribute the divine status of Jesus in the beliefs and cultic practice of earliest Christianity to this. I have considered Casey's theory and found it deficient, preferring my own analysis of matters (LJC, pp. 349-407, esp. 402-407). ${ }^{11}$

In my view the process of antagonistic differentiation between believers

Jesus, used the term in ways that overlap Johannine usage (e.g., 1 Cor. 9.20; 2 Cor. 11.24; Gal. 2.13-15; 1 Thess. 2.14).

9. Casey accuses me of 'regrettably inaccurate comments' in characterizing his view of the matter. If I have misconstrued him, entirely unintentionally, I very much regret it. But it is not really clear to me that my characterization of his theory is so very wide of the mark. I certainly regret not citing his book, Is John True?, which I did consult but found its argument not really any advance upon that set forth in his 1991 volume.

10. Shaye Cohen proposed that Jewish religious authorities of the post- 70 CE period should be seen as striving to rid Judaism of sectarian groups (Shaye J.D. Cohen, 'The Significance of Yavneh: Pharisees, Rabbis and the End of Jewish Sectarianism', HUCA 55 [1984], pp. 27-53). With their exclusivist claims for Jesus, Jewish Christians easily qualified as unacceptably sectarian.

11. As to Casey's suggestion that the exalted status of Jesus in Pauline Christianity might be attributed to Paul having to 'assimilate significantly when conducting the Gentile mission', I can only refer readers to my extended discussion of the data in my chapters on 'Pauline Christianity' and 'Judean Christianity' in LJC (chs. 2-3). 
in Jesus and the main part of the Jewish people began much earlier than in Casey's theory (e.g., the 'persecution' of Jewish Christians by Saul of Tarsus), and was initially a highly charged issue among Jews. ${ }^{12} \mathrm{We}$ do not have to wait for a putatively influential 'Gentile self-identification' in Johannine Christianity (or in Pauline Christianity either) to find Jesus treated as having a divine status or to find serious antagonism over this issue within the larger Jewish communities of the Roman period. ${ }^{13}$ Granted, however, in the post-70 $\mathrm{CE}$ period this antagonism led to more decisive measures against Jewish Christians on the part of Yavnean-inspired authorities, and a correspondingly increased rhetoric of condemnation against Jewish religious authorities from Christians.

\section{Historical Analysis and Theological Anxiety}

Finally, I find it curious that Professor Casey begins and ends his essay with statements asserting major theological-confessional issues at stake in these historical questions. ${ }^{14}$ In $L J C$ (esp.pp. 8-11) I lay out reasons for my view that the historical questions on the one hand, and theological questions about the nature and validity of Christian beliefs about/in Jesus on the other, need not have the rather (overly) simple relation that is reflected in Casey's statements. Each type of inquiry is sufficiently important and difficult in its own right that I think it unwise to make the answers to one depend upon the other too simply. In particular, to pursue historical analysis with the expectation either of legitimating or de-legitimating this or that form of contemporary Christian faith seems to me to introduce unnecessary and unhelpful theological anxiety into an already demanding task of careful historical analysis.

Certainly, historical questions about the origins and development of devotion to Jesus are 'of fundamental importance', not merely or even primarily to determine simply whether traditional Christian doctrines

12. Casey accuses me of having no proper notion of 'boundary markers', although, actually, I use the category in $L J C$, including the section where I discuss developments in Johannine Christianity (pp. 351-53; and see also p. 43). So the real issue is whether Casey's or my use of the category best fits the evidence.

13. Larry W. Hurtado, 'Pre-70 C.E. Jewish Opposition to Christ-Devotion', JTS 50 (1999), pp. 35-58.

14. As Casey does not follow me in admitting his own religious stance ( $L J C$, p. 9), I am at a disadvantage in wondering why these theological questions exercise him so much, and why he presumes such a rather simple approach to them. 
should continue to be held. Dear me, the latter question involves far more than the historical issues that I address in $L J C$ ! These historical questions are of fundamental importance more directly for working toward an adequate understanding of what identified earliest Christianity, what drove and shaped it, why it survived despite opposition and its modest beginnings, what religious diversity it comprised, and how it became the remarkably confident and successful religious movement that we see already before Constantine gave it imperial sanction. My hope is that, whatever the religious persuasions of its readers, $L J C$ will contribute to a clearer grasp of the importance of these historical questions, and (if I am candid) may even help to shape what are taken to be good answers to them. Professor Casey's generally positive judgment gives me hope that these may not be entirely vain aspirations. 